\title{
A razão da ilha e a razão do continente: Nietzsche em disputa, nos velhos campos da batalha filosófica
}

\author{
Fernando Costa Mattos \\ Professor de filosofia na UFABC e pesquisador do CEBRAP.
}

\begin{abstract}
Resumo: Este artigo se propõe a confrontar, a partir de apresentações resumidas de seus principais argumentos, duas tradições da interpretação nietzschiana: a francesa e a analítica. Ao final, procuramos fazer um balanço da confrontação, reconhecendo os prós e contras de cada posição: se a tradição analítica tem o mérito de exigir a maior precisão possivel na fundamentação dos argumentos filosóficos, ela parece pecar pela estreiteza de seus critérios; se a tradição francesa, por seu turno, derrapa no paradoxo do relativismo, sua ênfase na riqueza simbólica da obra nietzschiana permitiria conservar os seus conceitos fundamentais sem o risco de dogmatizá-los.
\end{abstract}

Palavras-chave: leituras francesas de Nietzsche filosofia analítica - perspectivismo - teoria do conhecimento - concepções de verdade
Abstract: This paper aims at establishing a confrontation between two traditions of the nietzschean interpretation: the french, and the analytical. After presenting an aproximative synthesis of its main arguments, at the end I propose a balance of this confrontation, trying to point out the pros and cons of each position: if the analytical tradition has the advantage of requiring the greatest precision as possible in the grounding of the philosophical arguments, it has the disadvantage of adopting too narrow criteria; if the french tradition, in its turn, tends to fall into the paradox of relativism, its emphasis on the symbolic richness of Nietzsche's thought allows us to preserve his fundamental concepts without the risc of dogmatizing them.

Key-Words: french readings of Nietzsche - analytical philosophy - perspectivism - theory of knowledge - conceptions of truth

\section{Apresentação}

Buscaremos aqui confrontar, a partir de apresentações resumidas e aproximativas de seus principais argumentos, duas tradições do comentário nietzschiano: a francesa e a analítica, cuja força é sabidamente grande nos países anglo-saxões. Enquanto a primeira, lançando mão de uma interpretação predominantemente relativista, enfatiza o caráter corrosivo das críticas nietzschianas, a segunda procura submeter o filósofo a uma análise lógica de seus argumentos, trazendo à luz, por um lado, aquela que seria a sua concepção de verdade e, por outro, deixando de fora os elementos supostamente "metafísicos" de seu 
pensamento. Ao final, procuramos fazer um balanço da confrontação, reconhecendo os prós e contras de cada posição: se a tradição anglo-saxã tem o mérito de exigir a maior precisão possível na fundamentação dos pensamentos filosóficos, ela pecaria pela estreiteza de seus critérios, cuja aplicação rigorosa implicaria condenar à extinção boa parte da história filosófica; se a tradição francesa, por seu turno, derrapa no paradoxo do relativismo, sua ênfase na riqueza simbólica de Nietzsche permite conservar os pensamentos fundamentais do filósofo sem incorrer no risco de dogmatizá-los. Com isso, portanto, acabamos por sugerir a preferibilidade leitura francesa - ou continental - de Nietzsche, em detrimento da anglo-saxã - ou insular, para recorrer desde logo à metáfora geográfica que serve de fio condutor a nosso balanço final. ${ }^{1}$

\section{O perspectivismo de Nietzsche na ótica de seus intérpretes franceses}

É desnecessário lembrar, talvez, a impressionante variedade de interpretações suscitadas pela obra nietzschiana: o filósofo aparece ora como um suposto metafísico, a avançar teses fortes acerca da essência do ente (leitura que tem em Heidegger seu principal defensor); ora como um pensador que se abre ao ser, à maneira pré-socrática (heraclítica), deixando virem à palavra o lúdico e a inocência do mundo; ora como o perspectivista cético que se admite a todo tempo como mera interpretação; e assim por diante.Se Nietzsche, pois, é tudo isso,

1. Evidentemente, a menção a essas duas tradições não tem qualquer pretensão exaustiva: há diversas outras correntes interpretativas cujos méritos e deméritos teriam de ser discutidos num balanço de maior fôlego. Em nossa tese de doutorado, por exemplo, abordamos de maneira mais detida, além dos intérpretes franceses e analíticos, a tradição iniciada por Heidegger, que vê em Nietzsche o "último metafísico do Ocidente"; aquela que vê na cosmologia nietzschiana uma efetiva superação da metafísica, tendo em Wolfgang Müller-Lauter e ScarlettMarton dois de seus mais notáveis defensores; e ainda aqueles que inserem Nietzsche na tradição crítica kantiana, como Friedrich Kaulbach, VolkerGerhardt e Antônio Marques. No presente artigo, porém, concentramos nossa análise apenas no debate entre as escolas francesa e anglo-saxã, uma disputa cujos lances, como se sabe, estendem-se para além da discussão sobre a obra nietzschiana. Cf. Mattos, F. C. Nietzsche e o primado da prática: um espírito livre em guerra contra o dogmatismo. Tese de doutorado. 271 páginas. São Paulo: Depto. de Filosofia - FFLCH - USP, 2007, cap. 1. 
e tudo isso ao mesmo tempo, ${ }^{2}$ talvez fosse mais razoável levar a sério algumas de suas afirmações a esse respeito e considerar a sua obra não como um sistema acabado e coerente de pensamento, à moda tradicional, mas sim como o mosaico assistemático de perspectivas que já o seu estilo aforismático por si só sugeriria, restando excluída qualquer fronteira rígida entre forma e conteúdo (de um modo tal que este pudesse ser dito sistemático à revelia daquela, ou algo assim). É o que o próprio filósofo parece indicar, quando nos fala acerca da sintonia entre a multiplicidade fluida de seus estados interiores - as vivências a partir das quais se formam suas perspectivas - e o estilo variado e cambiante de seus escritos - as próprias perspectivas em sua configuração simbólico-textual:

Comunicar um estado, uma tensão interna de pathos por meio de signos, inclú́do o tempo desses signos - eis o sentido de todo estilo; e considerando que a multiplicidade de estados interiores é em mim extraordinária, há em mim muitas possibilidades de estilo - a mais multifária arte do estilo de que um homem já dispôs. (...) A arte do grande ritmo, o grande estilo dos períodos, para expressar um imenso fluir e refluir de paixão sublime, sobre-humana, foi descoberto somente por $\operatorname{mim}_{i}$ com um ditirambo como o último do terceiro Zaratustra, intitulado 'Os sete selos', voei milhares de milhas acima e além do que até então se chamava poesia. ${ }^{3}$

Sugerindo uma resposta também à intrincada questão da comunicação filosófica, esse excerto do Ecce Homo nos leva a cogitar a possibilidade de uma relação homogênea entre a auscultação do

2. Embora, é claro, a periodização de sua obra permita estabelecer momentos que correspondem mais ou menos a tal ou qual posição, isso não elide a circunstância de que as diferentes posições também aparecem conjugadas ao longo das obras, assim como não impede um comentador de propor-se a ver o conjunto da obra fazendo abstração de tais distinções periódicas.

3. EH, "Por que escrevo livros tão bons", 4. Quando disponíveis as traduções de Nietzsche feitas por Rubens Rodrigues Torres Filho para a coleção Os pensadores (Ed. Abril Cultural), nós as adotaremos aqui. Quando não disponíveis, adotamos aquelas de Paulo César de Souza para a coleção das obras de Nietzsche publicada pela Companhia das Letras. As referências às obras de Nietzsche serão feitas segundo as abreviaturas habituais em português: EH para o Ecce Homo, BM para Além do bem e do mal, GM para Genealogia da moral e ZAR para Assim falou Zaratustra. 
mundo, tal como Zaratustra a obtém da solidão e da natureza, o eco interior dessa vivência múltipla, intensamente ruminada pelo filósofo, e, enfim, a sua expressão em signos numa literatura de novo tipo, capaz de conservar no texto o pathos fundamental, mas sempre múltiplo, de todo esse complexo processo. Ao leitor de Nietzsche, desse ponto de vista, restaria lançado o desafio não de interpretar os textos em busca dos conceitos basilares do suposto sistema filosófico, mas sim de penetrar a sua atmosfera fluida e instável na tentativa de partilhar algo do vivido e comunicado pelo autor - não, portanto, através de uma leitura "científica" que pudesse precisar o sentido desta ou daquela idéia desenvolvida pelo autor, mas através de uma sondagem ao mesmo tempo cuidadosa e fluida que deixasse viver as metáforas por ele criadas. É nessa direção, quer parecer-nos, que se encaminha a leitura de Derrida, a qual, em aberta confrontação dialógica com Heidegger ${ }^{4}$ sugere levar mais a sério as imagens nietzschianas - por exemplo aquela que identifica verdade e mulher - como chaves para pensar o estado das velhas questões filosóficas em Nietzsche:

A partir do momento que a questão da mulher suspende a oposição decidível entre o verdadeiro e o não-verdadeiro, instaura o regime epocal das aspas para todos os conceitos pertencentes ao sistema dessa decidibilidade filosófica, desqualifica o projeto hermenêutico que postula o sentido verdadeiro de um texto, liberta a leitura do horizonte do sentido do ser ou da verdade do ser, dos valores de produção do produto ou de presença do presente, o que se desencadeia é a questão do estilo como questão da escritura, a questão de uma operação perfurante (éperonnante) ${ }^{5}$ mais poderosa que qualquer conteúdo, tese ou sentido. ${ }^{6}$

Derrida opera assim, em relação à leitura de Heidegger, uma guinada de cento e oitenta graus: não mais se busca o "sentido verda-

4. Derrida não só respeita a leitura de Heidegger, chamando a atenção para a sua muitas vezes negligenciada complexidade, como ainda a toma enquanto principal contraponto dialógico - sentido em que falamos aqui nessa "aberta confrontação dialógica". Cf. Derrida, J. Éperons. Les styles de Nietzsche. Paris: Flammarion, 1978.

5. Traduzimos éperonnantepor perfurante no intuito de conservar as imagens conotadas pelos termos éperons, éperonnante etc., cuja centralidade no texto de Derrida é atestada pelo seu próprio título: Éperons.

6. Derrida, J. Éperons.Les styles de Nietzsche, p. 86) 
deiro" do texto, ou, no texto, o "sentido do ser ou da verdade do ser", mas a questão do estilo ou da escritura, uma questão "mais poderosa que qualquer conteúdo, tese ou sentido". Deste ponto de vista, com efeito, cairiam por terra todas as considerações acerca da verdade (sem aspas) do texto nietzschiano, bem como todas as discussões acerca daquilo que fosse a verdade para ele, isto é, a sua "teoria do conhecimento" à moda clássica: concorde neste ponto com Heidegger - que também descarta a presença de tal "disciplina" no pensamento nietzschiano $^{7}-$, Derrida reverte porém as conseqüências daí deriváveis, insistindo na ausência de uma pretensão metafísica forte, de um discurso unívoco que pretendesse dar conta da essência do ente. Nietzsche seria mesmo o filósofo da pluralidade por excelência, aquele que reconhece em si diversas "verdades" e que busca trazê-las ao texto na forma de imagens igualmente plurais, num processo lúdico - um jogo - de mascaramento, dissimulação, distanciamento e sedução que se deixaria bem representar pela imagem da mulher, ou, melhor, das mulberes, no plural:

Não há uma mulher, uma verdade em si da mulher em si, isso ao menos ele o disse, e [daí] a tipologia tão variada, a multidão das mães, filhas, irmãs, solteironas, esposas, governantas, prostitutas, virgens, avós, pequenas e grandes moças de sua obra.

Por essa razão mesma não há uma verdade de Nietzsche ou do texto de Nietzsche.

Quando lemos em Jenseits 'elas são apenas minhas verdades', sublinhando o 'meineWahrheitensind', é justamente num parágrafo sobre as mulheres. Minhas verdades: isto implica sem dúvida que não há aí verdades, já que elas são múltiplas, matizadas, contraditórias. Não há portanto uma verdade em si e, além disso, mesmo para mim, em mim, a verdade éplural. ${ }^{8}$

Com isso, vemo-nos diante do sentido mais forte do perspectivismo nietzschiano, ora colocado na base de seu pensamento não como solo epistemológico para as demais "teses", mas como elemento estilístico que, na ausência de fronteira entre "forma" e "conteúdo", atravessa as suas "águas", qual um "navio de velas brancas planando

7. Cf. Heidegger, M. Nietzsche, vol. 1. Tradução de Marco Antônio Casanova. Rio de Janeiro: Forense, 2007, pp. 386 e ss.

8. Derrida, J. Éperons.Les styles de Nietzsche, p. 83. 
sobre o mar como uma borboleta", ${ }^{9}$ a infiltrar a pluralidade em todos os supostos "conceitos" e a eliminar, assim, a possibilidade de interpretações unívocas que definissem, por exemplo, o que é o eterno retorno, o que é a vontade de potência etc. E assim a obra de Nietzsche perderia o caráter de um quadro conceitual sistemático, a fornecer uma visão metafísica do mundo, passando a poder ser vista como um repertório variado de imagens e signos, a fornecer diferentes perspectivas de abertura para o mundo, diferentes chaves para não apenas pensá-lo, mas também senti-lo e vivê-lo. Daí, possivelmente, a insistência do próprio autor em descrever a sua obra não como um conjunto de textos a serem lidos e interpretados, mas como um lugar ou atmosfera a ser penetrada e vivida pelo leitor (desde que este partilhe minimamente alguns dos pressupostos vivenciais próprios ao autor, para que possa haver comunicação entre as perspectivas):

Quem sabe respirar o ar de meus escritos sabe que é um ar da altitude, um ar forte. É preciso ser feito para ele, senão o perigo de se resfriar não é pequeno. O gelo está perto, a solidão é descomunal - mas quão tranquilas banham-se as coisas na luz! Com que liberdade se respira! Quantas coisas sente-se abaixo de si $!^{10}$

E se trata de um lugar, como se vê, ao mesmo tempo inóspito e tranquilo, inabitável para os fracos, prazeroso para os fortes - assim como a imagem do navio, proposta por Derrida, envolvia tanto a ponta aguda da proa, a cortar as águas com violência, quanto a tranquilidade de quem está lá em cima, sobre o barco. De um lado, pois, a crítica virulenta à tradição filosófica, cujos conceitos unívocos são como que cortados ao meio; de outro, a calmaria da solidão, a imagem da criança jogando como chave para pensar a inocência do mundo, inocência com que se vê reconciliado, justamente, o filósofo que foi capaz daquela dureza na luta contra o dogmatismo, no abandono das confortáveis certezas oferecidas por este. Se tomarmos, então, esta

9. Idem, p. 33. Éperon também tem o sentido de ponta da proa de um navio, donde a escolha de mais essa imagem por Derrida.

10. EH, Prólogo, 3. A tradução é de Rubens Rodrigues Torres Filho, mas, por razões estilísticas, preferimos as soluções de Paulo César de Souza para os trechos "quão tranquilas banham-se as coisas na luz" e "quantas coisas sente-se abaixo de si", em detrimento de, respectivamente, "com que tranquilidade estão todas as coisas à luz!" e "quanto se sente abaixo de si". 
dupla dimensão contida no locus textual nietzschiano - e para Derrida todo texto é mesmo um locus, de que o próprio autor-sujeito sequer faz parte -, podemos encarar a obra de Nietzsche como uma espécie de lente multifacetada, através da qual se pode enxergar a realidade sem nunca fechar-se numa única perspectiva, e os seus "conceitos", como imagens polissêmicas - necessariamente polissêmicas - a servir de instrumentos tanto para pensar essa realidade, brincando com os diferentes ângulos, como para dissecar e destruir as formas unívocas - e por isso dogmáticas - de compreensão do mundo.

Desse ponto de vista, a leitura de Derrida, à parte suas características singulares, e mesmo seu relativo parentesco com a de Heidegger, poderia ser aproximada daquilo que se tornou uma espécie de tendência comum a boa parte dos intérpretes franceses de Nietzsche: tomar a obra deste como "caixa de ferramentas", ou como "instrumento de trabalho", para, em contraste com a tradição metafísica, interrogar criticamente a realidade e a história do mundo ocidental. Gérard Lebrun, por exemplo, que também recusa todo e qualquer caráter ontológico a noções como a vontade de potência - ao designá-la como essência da vida, Nietzsche estaria sobretudo zombando dos definidores de essências ${ }^{11}-$, assume uma tal perspectiva ao afirmar, em resposta à questão "Por que [e como] ler Nietzsche hoje?", que

em vez de uma teoria do conhecimento e de uma ontologia, é-nos proposta uma estratégia de interpretação. Mas, que outra coisa pretender, quando lemos Nietzsche hoje? Muito se enganaria quem pretendesse travar contato com um filósofo a mais. Nietzsche não é um sistema: é um instrumento de trabalho - insubstituível. Em vez de pensar o que ele disse, importa acima de tudo pensar com ele. Ler Nietzsche não é entrar num palácio de ideias, porém iniciar-se num questionário, habituar-se com uma tópica cuja riqueza e sutileza logo tornam irrisórias as 'convicções' que satisfazem as ideologias correntes. $^{12}$

"Questionário" e "tópica": nos termos de Lebrun, temos de novo o duplo aspecto do pensar nietzschiano, ora movendo-se com interrogações na contramão de todo pensamento tradicional (ideológico),

11. Lebrun, G. "Por que ler Nietzsche hoje?". In: Passeios ao léu. São Paulo: Brasiliense, 1983, p. 37.

12. Idem, p. 38 . 
ora oferecendo metáforas topográficas, de notáveis riqueza e sutileza, para que possamos, "pensando com ele", criar sentidos ao viver humano. Recusando todos os "ismos" que pudéssemos tentar juntar "a mais este filósofo" - ele se refere explicitamente, no artigo citado, a ceticismo, diletantismo, niilismo e biologismo, mas também o eventual "nietzschianismo" fica implícito na lista ${ }^{13}$-, Lebrun insiste, como Derrida e outros comentadores franceses, no caráter perspectivo, plural e problemático do pensamento nietzschiano, no sentido de ele não assumir determinados "conceitos" a não ser enquanto ideias problemáticas, hipóteses provisórias, instrumentos, enfim, a serviço desse movimento mais geral de oposição ao velho e abertura ao novo. Assim, segundo Lebrun, nada de enxergar fixações conceituais, teses científicas ou, em geral, posições dogmáticas, mesmo ali onde a tentação seria fazê-lo, como, por exemplo, em algumas explicações "históricas" da Genealogia, considerada por alguns como o livro nietzschiano de formato mais "tradicional": ${ }^{14}$

Todos os instintos que não se descarregam para fora voltam-se para dentro - é isto o que eu denomino a interiorização do homem: é somente com isso que cresce no homem aquilo que mais tarde se denomina sua 'alma'. O inteiro mundo interior, originariamente delgado como algo retesado entre duas peles, separou-se e aumentou, adquiriu profundeza, largura, altura, na medida em que a descarga do homem para fora foi obstruída. Aqueles terríveis baluartes com que a organização estatal se protegia contra os velhos instintos da liberdade - os castigos fazem parte, antes de tudo, desses balu-

13. Lebrun sempre foi um crítico de todos aqueles que se aferram ao pensamento de Nietzsche como se ele fosse verdadeiro, assumindo a condição de discípulos em sua defesa. Não é à toa que o artigo em questão é aberto com a seguinte consideração: "Marx gostava de dizer que não era 'marxista', mas não detestava que outros o fossem. Nietzsche, ao que parece, não teria gostado que houvesse nietzschianos: 'Apliquei o ouvido para escutar um eco, e só recolhi elogios.' BM, 99. 'Mihiipsiscripsi', dizia após concluir um livro, e Lou-Salomé garante-nos que nesta expressão não havia nenhuma afetação de esteta." Lebrun, G. "Por que ler Nietzsche hoje?", p. 32. Na sequência, Lebrun traz ao texto diversas passagens do Zaratustra que recusam a ideia dos discípulos, dos "crentes" em Zaratustra ou em quem quer que seja.

14. Deleuze, por exemplo, afirma que "a Genealogia da moral é o livro mais sistemático de Nietzsche". Deleuze, G. Nietzsche et la philosopbie. Paris: PUF, 1999, p. 89 . 
artes - acarretaram que todos aqueles instintos do homem selvagem, livre, errante, se voltassem para trás, contra o bomem mesmo. A hostilidade, a crueldade, o gosto pela perseguição, pelo assalto, pela mudança, pela destruição - tudo isso se voltando contra os possuidores de tais instintos: essa é a origem da 'má consciência'. ${ }^{15}$

Bem se poderia dizer que, nesse ponto da Genealogia, tendo descartado outras hipóteses explicativas para o fenômeno da "má consciência" ao longo de um percurso que gradativamente preparava terreno para a conclusão aí apresentada, Nietzsche estaria dando mostras de um típico procedimento filosófico ou científico tradicional: posto um determinado problema - a "má consciência", presente no próprio título da segunda parte do livro -, ele estaria tentando resolvê-lo por meio de uma hipótese explicativa de caráter histórico, elucidando-o a partir de sua origem nas sociedades humanas primitivas. E a peremptoriedade da afirmação final, com grifo do próprio filósofo - "esta é a origem..." -, não deixaria dúvidas quanto à pretensão de ter mesmo resolvido o problema, podendo a partir disso, inclusive, propor ideias sobre como lidar com ele no futuro - tarefa que ficaria a cargo de uma "nova era" e de "novos homens" (de existência incerta) cujo sentido ele próprio já deixaria indicado. ${ }^{16} \mathrm{Ou}$ seja: problema diagnosticado, problema explicado, solução indicada - elementos típicos de um procedimento teórico tradicional.

Segundo Lebrun, porém, tais elementos não chegariam a representar uma recaída dogmática de Nietzsche porque, acompanhados sempre de sua contraparte atenuante ou relativizante - a explicação sobre a má consciência, por exemplo, fôra precedida de uma ressalva quanto a tratar-se de "uma primeira, provisória expressão da minba própria bipótese"17 -, eles não podem mesmo passar de meras ficções, a serviço de um pensar hermenêutico que se sabe perspectivo mesmo quando parece aspirar a alguma objetividade - como seria o caso da Genealogia. Não é à toa que Foucault, cujos vínculos com Nietzsche, e em particular com o seu pensar genealógico, são sabidamente grandes, seja outro francês a entrar nessa cruzada contra as interpretações "dogmatizantes" de Nietzsche, procurando mostrar em que medida o

15. GM, II, 16.

16. Referimo-nos ao que Nietzsche dirá no § 24 dessa mesma parte: "vincular a má consciência a todas as inclinações antinaturais..." GM, II, 24.

17. GM, III, 16. 
procedimento genealógico se distancia dos demais modos de interpretar a história justamente porque não se dissocia das condições singulares que o fundam enquanto perspectiva:

[A história efetiva de Nietzsche] não tem medo de ser um saber perspectivo. Os historiadores tentam, na medida do possível, apagar aquilo que pudesse denunciar, no seu saber, o lugar de onde olham, o momento em que estão, o partido que tomam, - o incontornável de sua paixão. O sentido histórico, tal como Nietzsche o entende, sabe-se perspectivo e não recusa o sistema de sua própria injustiça. Ele olha sob um certo ângulo, com o propósito deliberado de apreciar, dizer sim ou não, seguir todos os traços do veneno, encontrar o melhor antídoto. Em vez de fingir um discreto apagamento diante daquilo que olha, em vez de buscar neste a sua lei e a ela submeter cada um de seus movimentos, esse olhar sabe de onde olha tão bem quanto sabe o que olha. ${ }^{18}$

Ao mesmo tempo que "observa o mundo", portanto, podendo assumir os ares de um teórico tradicional que "descreve o que vê", o genealogista "observa a si mesmo" como se carregasse consigo um espelho, sempre diante de si, a impedi-lo de "olhar" o mundo sem reencontrar-se a todo tempo a si mesmo: esse duplo e paradoxal modo de pensar - olhar, como perspectiva, não passam naturalmente de imagens para o pensar-, que com Foucault percebemos constituir também o núcleo da genealogia nietzschiana, seria mesmo a marca distintiva do filósofo alemão, a separá-lo decisivamente da tradição filosófica ali onde ele parecia dela aproximar-se. Na mesma linha de Lebrun, Foucault insiste assim na indissociabilidade de pensamento, de um lado - formulado em metáforas e ficções hermenêuticas -, e vivências singulares do filósofo, de outro lado - "o incontornável de sua paixão" que Nietzsche, escapando à hipocrisia dos objetivistas de todo gênero, não tem qualquer vergonha em assumir. Sem isso, com efeito, ficaria difícil explicar a mistura de elementos "subjetivos" e "objetivos" - as aspas se fazem aqui imprescindíveis - que os textos de Nietzsche apresentam a todo tempo, sendo bom exemplo disso aquele mesmo parágrafo da Genealogia em que Nietzsche se nos afigurava tão "tradicional" e que é concluído, pouco após o trecho acima citado, com os seguintes pensamentos:

18. Foucault, M. "Nietzsche, la genealogie, l'histoire". In: Balaudé, J-F. eWotling, P. (orgs.) Lectures de Nietzsche. Paris: Le Livre de Poche, 2000, pp. 120-1. 
De fato, seria preciso espectadores divinos para dar valor ao espetáculo que começou com isso e cujo fim é ainda impossível de ver - um espetáculo refinado demais, maravilhoso demais, paradoxal demais, para que pudesse desenrolar-se insensatamente despercebido sobre algum astro ridículo! $\mathrm{O}$ homem conta desde então entre os mais inesperados e emocionantes lances de dados que a 'grande criança' de Heráclito, chame-se Zeus ou Acaso, joga - ele desperta um interesse por si, uma tensão, uma esperança, quase uma certeza, como se com ele se anunciasse algo, se preparasse algo, como se o homem não fosse um alvo, mas somente um caminho, um episódio, uma ponte, uma grande promessa... ${ }^{19}$

Num comentário que por si só, enquanto comentário ao que seria uma explicação objetiva, já se afasta inteiramente dos moldes científicos mais rigorosos, e em meio a essa atmosfera de remissão a Heráclito, cujo caráter de contraponto, com relação à tradição platônica-ocidental, é sabidamente enfatizado por Nietzsche, vemos uma abundância de adjetivos e sentimentos que, não tendo aparecido nos momentos imediatamente anteriores do texto, serviriam bem para ilustrar aquela circunstância de fusão entre o "objetivo" e o "subjetivo", entre o objeto "observado" e o ponto de vista do "observador", de que há pouco vimos Foucault falar. Ao escrever a Genealogia, com efeito, e mesmo sua obra como um todo, Nietzsche está mergulhado numa luta, sobretudo contra o seu tempo - o "medíocre homem moderno" -, que se enraíza numa essencial falta de afinidade com relação a este, bem como nos sentimentos daí decorrentes: ódio por tudo aquilo que o inimigo representa, amor por tudo aquilo que lhe parecem alternativas antagônicas (como o mundo grego) e assim por diante. Ora! Enquanto um pensador tradicional buscaria ocultar todos esses elementos passionais de seus textos explicativos (e em geral de si próprio), tentando provar que a sua posição seria de fato a mais acertada (sem nunca consegui-lo), Nietzsche não se envergonha de assumi-lo, trazendo sempre ao texto as suas idiossincrasias, confessando abertamente o seu "pathos agressivo". ${ }^{20}$

Se assim é, parece então bastante razoável que não apenas reconheçamos o caráter pessoal e, porque pessoal, plural do pensamento de Nietzsche - a pluralidade seria também um dado da sua singularidade,

19. GM, II, 16.

20. EH, "Por que sou tão sábio", 7. 
quiçá faltante em indivíduos de menor riqueza interior-, mas também que admitamos nossas próprias paixões, nossos interesses, nossos sentimentos, à medida que percorremos o rico universo de seus textos. Esta é uma virtude, com efeito, que parece estar presente na leitura proposta por autores como Derrida, Lebrun e Foucault: se Nietzsche lhes serve tão bem como instrumento de trabalho, é justamente porque seus pensamentos, ecoando de algum modo as idiossincrasias dos próprios "comentadores" - palavra que, por sinal, mostra-se aqui inapropriada-, abrem-se a leituras (ou "usos") que permitem intensificar ainda mais a identificação, transpondo-se ao mesmo tempo a luta nietzschiana para uma outra época e um outro contexto, nos quais esses autores travam suas próprias lutas (contra novas formas do mesmo "homem moderno"). ${ }^{21}$ Com isso eles estariam, de qualquer modo, sendo mais fiéis ao "mestre" - aquele que demanda de seus discípulos não serem discípulos, mas "espíritos livres" ${ }^{122}$ - do que quem quer que pretendesse estabelecer a interpretação verdadeira do texto nietzschiano:

21. Destoando um pouco de seus conterrâneos, Deleuze, cuja leitura é aliás anterior à deles, propõe em Nietzsche et la Pbilosophie uma compreensão mais sistemática do todo da obra, que lê em paralelo com a obra crítica kantiana. Mesmo assim, ele não deixa de partilhar o pressuposto relativista, comum aos franceses, no modo de compreender o perspectivismo: "Ora, não há verdade que, antes de ser uma verdade, não seja a efetuação de um sentido ou a realização de um valor. A verdade como conceito é inteiramente indeterminada. Tudo depende do valor e do sentido daquilo que pensamos. Nós temos sempre as verdades que merecemos em função do sentido daquilo que concebemos, do valor daquilo em que cremos." Deleuze, G. Nietzsche et la philosopbie, p. 118.

22. Referimo-nos à seguinte passagem: "Agora prossigo só, meus discípulos! E vós também, ide embora, sós! Assim o quero./ Afastai-vos de mim e defendei-vos contra Zaratustra! Melhor: envergonhai-vos dele! Talvez ele vos tenha enganado./ O homem do conhecimento deve poder não somente amar seus inimigos, como também odiar seus amigos./ Retribui-se mal a um mestre, continuando-se sempre apenas aluno. E por que não quereis arrancar louros da minha coroa?/ Vós me venerais; mas e se um dia vossa veneração desmoronar? Guardai-vos de que não vos esmague uma estátua!/ Dizeis que acreditais em Zaratustra? Mas que importa Zaratustra! Sois os meus crentes, mas que importam todos os crentes!/ Ainda não vos havíeis procurado: então me encontrastes. Assim fazem todos os crentes; por isso valem tão pouco todas as crenças./ Agora ordeno que me percais e vos encontreis, e somente quando me tiverdes todos renegado retornarei a vós..." (ZAR, I, "Da virtude da- 
eles leem Nietzsche segundo uma perspectiva que se sabe perspectiva, seguindo a propósitos que se reconhecem como tais, e assim por diante - exatamente como Nietzsche se teria proposto a ler o "livro do mundo".

\section{A filosofia analítica e os pressupostos implícitos da fala nietzschiana}

Seria de reconhecer-se, no entanto, que, assim como o perspectivismo não é capaz de refutar, no sentido mais forte da palavra, as teses unívocas que com ele se defrontam, também essa espécie de "metaperspectivismo" defendido pelos franceses - toda perspectiva (textual) só pode ser vista a partir de outra perspectiva - é incapaz de refutar o seu contrário, isto é, uma tese unívoca, pretensamente objetiva, que procurasse estabelecer a verdade do perspectivismo de Nietzsche. À parte eventuais considerações (bastante nietzschianas) acerca da eventual "univocidade" das vivências singulares "por trás" de tais leituras, o fato é que elas encontram seu direito de existência, por assim dizer, no pensamento mesmo do filósofo. ${ }^{23}$ Não é de estranhar, assim, que tantas leituras diferentes, concorrendo umas com as outras, tenham caminhado nessa direção, procurando firmar não apenas a verdade do texto nietzschiano - algo de que o próprio Heidegger seria um exemplo - como, eventualmente, a verdade (ou inverdade) de alguns de seus conceitos. E deste último ponto de vista o perspectivismo, por exemplo, poderia ser inscrito no quadro mais geral de uma teoria do conbecimento em sentido forte, isto é, uma teoria contendo uma dada concepção de verdade, estabelecendo os limites do conhecimento

divosa". Citado a partir da tradução de Paulo César de Souza para oEcce Homo, onde Nietzsche, no Prólogo, reproduz essa passagem.)

23. É curioso como, ao justificar sua abordagem assumidamente analítica da obra nietzschiana, Steven Hales e RexWelshon usam justamente o argumento de que Nietzsche esperava discípulos que não fossem propriamente discípulos para sustentar a validade de uma abordagem a partir de um solo tão flagrantemente distinto daquele dos textos nietzschianos: "Nietzsche escreveu que 'se retribui mal a um professor quando se permanece apenas aluno' (ZAR, I). Não encontrar uma voz contemporânea, tentar enquadrar-nos em um molde 'propriamente' nietzschiano, seria retribuir-lhe mal." Hales, S. e Welshon, R. Nietzsche's Perspectivism. Chicago: University of Illinois Press, 2000, p. 5. 
humano etc; uma posição, portanto, que neste ponto se coloca em polo oposto ao dos franceses.

Referimo-nos a certa tradição de comentário nietzschiano formada no bojo da filosofia analítica, cuja força é sabidamente grande entre os pensadores anglo-saxões e que se coloca em posição de ostensivo confronto com as leituras francesas acima apresentadas. ${ }^{24}$ Para autores como, por exemplo, Arthur Danto, Peter Poellner e Maudemarie Clark, o relativismo nietzschiano, como aliás qualquer relativismo, não deve ser levado tão a sério, pois isso implicaria, sim, incorrer no problema da autorreferência e, portanto, da autorrefutação: se não apenas cada perspectiva, num sentido mais geral, mas cada palavra for tomada em sentido apenas metafórico, sem nenhuma referência semântica minimamente "objetiva", então todo e qualquer discurso se vê reduzido ao mais puro solipsismo, não havendo possibilidade de comunicação para além do apontar com o dedo, como já os mobilistas pré-socráticos teriam há muito se encarregado de mostrar. Se, ao contrário, tencionamos estabelecer algum tipo de comunicação dotada de sentido intersubjetivo, devemos reconhecer certos padrões mínimos, ou condições de possibilidade, em que estariam fundadas a nossa linguagem e a nossa comunicação. E a função de reconhecer e examinar tais padrões continuaria a ser exercida pela lógica e pela epistemologia, ainda que sem os "ranços metafísicos" de certa tradição "continental".

Em que pese a grosseira simplificação, tal é, em linhas gerais, o argumento comum a esses autores no que diz respeito à oposição que estabelecem frente aos leitores "relativistas" de Nietzsche, um argumento que começa a valer, antes mesmo da entrada nos temas nietzschianos propriamente ditos, para as próprias condições de possibilidade da exegese: se todas as leituras de Nietzsche fossem marcadas, em sua essência constitutiva, pelas condições pessoais do comentador, tal como há pouco sugerido, tornar-se-ia impossível estabelecer qualquer diálogo entre elas; tornar-se-ia sem sentido, a rigor, a própria ideia do comentário. Tomando como referência a leitura "relativista"

24. Esses mesmos autores (Hales e Welshon) assim descrevem sua filiação: "Nós abordamos Nietzsche a partir da perspectiva da filosofia analítica contemporânea. Embora não sejamos os primeiros a fazê-lo (Arthur Danto, Maudemarie Clark e Peter Poellner são óbvios precursores, e Richard Schacht e Alexander Nehamas são no mínimo companheiros de viagem)..." Idem, p. 6. 
de Derrida, para quem a "verdade" - do mundo ou do texto - seria antes, como vimos, um jogo de mascaramento e dissimulação, Poellner procura mostrar como a noção mesma de dissimulação só faz sentido se se reconhece, como seu contraponto conceitual, a noção de não-dissimulação, isto é, de palavras que não sejam dissimuladoras, mas sim denotadoras de um sentido adequado, e adequado do ponto de vista de certas condições de possibilidade que ele descreve como parte de um "uso público" da linguagem:

Que os significados das palavras e sentenças, no sentido por mim indicado, possam ser frequentemente 'excluídos' por nós, em virtude de nosso conhecimento do seu uso normal, é algo admitido pelo próprio Derrida. É somente porque temos esse conhecimento que podemos reconhecer alguns usos como paródias e que a dissimulação se torna possível - só é possível dissimular porque as palavras têm significados-padrão, públicos, que o dissimulador pode, e precisa, utilizar para seus propósitos. Quando, no que se segue, eu falar de uma interpretação de 'Nietzsche', entendo por isso, como muitos de seus leitores, uma interpretação da totalidade de seus textos (tardios) em termos de significados que são - usualmente - acessíveis porque fazem parte de uma linguagem pública. É por causa do que esses textos dizem, e não das ocasiões que oferecem para um 'livre' jogo associativo de palavras, que por mais de um século os leitores de Nietzsche, entre os quais o autor das presentes páginas, neles encontraram estímulo e interesse..$^{25}$

Confrontadas com o texto de Derrida, que lhe servia aí de interlocutor, e mesmo com boa parte das interpretações consagradas, as afirmações de Poellner são bastante surpreendentes: o nosso filósofo da solidão e das metáforas, que parece ver com absoluto desprezo tanto a tradição dos conceitos fixos como a mediocridade da "linguagem gregária", é agora apresentado como alguém que diz algo a seus leitores, através de seus textos, no sentido mais tradicional e corriqueiro da palavra "dizer". E essa seria, justamente, a razão para ter-se formado a gama tão variada de leitores e intérpretes a tentar estabelecer, como temos visto, o que Nietzsche realmente "quis dizer" - só obtendo verdadeiro sucesso, contudo, aqueles que se teriam baseado naquilo que seus textos de fato dizem, já que as intenções profundas do indivíduo Nietzsche, ou algo assim, jamais poderiam constituir objeto

25. Poellner, P. Nietzsche and Metapbysics. Oxford: Clarendon, 1995, p. 28. 
de um estudo sério. Entre os "analíticos", como se sabe, é pequeno o sucesso da velha distinção "continental" entre "espírito da obra" e "letra do texto": o que vale é esta última, e a sua análise tem de ser feita segundo critérios que repousem num mínimo de consenso intersubjetivo, pressuposto epistemológico que não apenas descarta o metaperspectivismo do leitor, como visto, mas demanda uma reinterpretação do perspectivismo do autor, isto é, aquele que Nietzsche nos disse.

É assim que Maudemarie Clark, por exemplo, ao tratar dessa questão, procura mostrar que a metáfora do perspectivismo ${ }_{,}{ }^{26}$ longe de implicar uma recusa de toda e qualquer objetividade cognitiva, representa antes um ataque específico à teoria metafísica da verdade como correspondência, entendida esta no seu sentido mais forte, isto é, como correspondência entre os nossos conhecimentos e ascoisas em si mesmas. ${ }^{27}$ Em outras palavras, Nietzsche estaria, com o seu perspectivismo, meramente corroborando a recusa kantiana do conhecimento da coisa em si, sem deixar de apresentar, como Kant, uma concepção de verdade a ela alternativa: depois de muitas hesitações, segundo Clark, Nietzsche teria acabado por ceder, na fase final de sua obra, ao que ela chama de "uma versão do senso comum da teoria da correspondência", ${ }^{28}$ basea-

26. Ela faz questão de frisar o caráter metafórico do perspectivismo, já que, embora um tanto óbvio, sua desconsideração poderia levar o leitor nietzschiano a equívocos: "Dado o absurdo ou a trivialidade da afirmação [do caráter perspectivo do conhecimento em GM, III, 12] quando lida num nível literário, nós assumimos que tais enunciados não são concebidos para transmitir informação num sentido direto. $\mathrm{O}$ caráter metafórico das afirmações perspectivistas de Nietzsche se torna evidente quando ele diz que as noções da razão pura e do 'conhecimento em si' sempre 'demandam do olho um absurdo e um sem-sentido'. Lida literalmente, esta afirmação não pode ser levada a sério. Os conceitos em questão concernem apenas ao conhecimento, e não demandam quaisquer crenças sobre a visão, por exemplo a de que a vida pudesse pertencer a 'um olho virado em direção nenhuma'. Como não podemos, razoavelmente, supor que Nietzsche acredite em algo tão absurdo, nós devemos interpretar seu (literalmente falso) enunciado como uma tentativa de fazer-nos notar certas semelhanças entre os conceitos cognitivos em questão e a absurda ideia de um ver não-perspectivo." Clark, M. Nietzsche on truth and philosophy. Cambridge: Cambridge Univ. Press, 1990, p. 129.

27. Idem, pp. 40 e ss., 129 e ss.

28. Idem, p. 31. 
da no princípio lógico da equivalência. ${ }^{29}$ Embora ele não a tenha propriamente desenvolvido e formulado enquanto teoria, ela seria a única compatível com a célebre seção de Crepúsculo dos Ídolos, para Clark fundamental, intitulada "Como o mundo verdadeiro se transformou em fábula": dada a recusa de Nietzsche em aceitar qualquer visão idealista do mundo, aí bastante clara, tal teoria seria a única a impedi-lo de entrar em sérias contradições quando "fala sobre o mundo"; quando fala, por exemplo, que "o ressentimento desempenha um papel decisivo nas avaliações morais":

Não-tradicionalistas que consideram a verdade metafísica parecem interpretar Nietzsche como se ele negasse que temos justificativa em pretender a verdade para nossas crenças quando estas carecem da certeza que apenas um sistema metafísico poderia fornecer. Mas nós não podemos exigir certeza das pretensões de verdade se não a requeremos de outros tipos de asserção. Ninguém acredita seriamente que a ausência do tipo de certeza fornecido pela metafísica obrigue Nietzsche a abster-se de afirmar que o ressentimento desempenha um papel decisivo nas avaliações morais. De acordo com o princípio da equivalência, se Nietzsche afirma (1) 'o ressentimento desempenha um papel decisivo nas avaliações morais', ele deve aceitar que (2) "o ressentimento desempenha um papel decisivo nas avaliações morais' é verdadeiro'. Mas se a asserção de (1) é justificada, e (1) implica (2), então a asserção de (2) também deve ser justificada. Nós podemos justificar a pretensão de que uma afirmação seja verdadeira na mesma medida em que podemos justificar o fato de fazer a afirmação. ${ }^{30}$

Trazendo-nos de volta a uma dificuldade fundamental do discurso nietzschiano, a argumentação de Clark recorre a um princípio lógico para mostrar como nenhum discurso se poderia sustentar sem a

29. Idem, pp. 33 e ss.

30. Idem, pp. 23-4. Note-se como tal excerto, à parte trazer-nos um ponto fundamental da leitura proposta por Clark, funciona também como uma boa amostra de um procedimento típico dos "analíticos", em franco contraste com os textos "continentais": recurso à lógica como fundamento para a argumentação desenvolvida; transposição da discussão exegética para um plano claramente extra-exegético (é ela quem defende o princípio da equivalência, não Nietzsche); preocupação em aproximar a filosofia da linguagem cotidiana; avaliação do autor clássico à luz da evolução posterior da filosofia (o que os "analíticos" chamam de "princípio da caridade"); etc. 
admissão, explícita ou implícita, de algum tipo de verdade ou crença: se Nietzsche, que a princípio teria gostado de excluir essas noções de suas próprias pretensões filosóficas, põe-se a falar com tanta convicção acerca, por exemplo, da psicologia moral humana, isto seria uma evidência, corroborada por uma ou outra sugestão indireta do próprio filósofo, ${ }^{31}$ de que ele, tendo deixado de lado as discussões metafísicas sobre o problema (nas quais se oscila entre o absoluto e o nada), teria afinal aceito uma versão mais branda da verdade, isto é, uma versão mais cotidiana, mais próxima ao que o senso comum entende por isso quando se diz, por exemplo, "É verdade que aí está chovendo?"; "Sim, é verdade". É isso o que Clark entende por "versão do senso comum da teoria da verdade como correspondência", ou "teoria da correspondência mínima", e que também se deixaria descrever, segundo ela, como uma posição neokantiana: ${ }^{32}$ afastadas em definitivo as grandes

31. Na verdade, é relativamente limitado o embasamento da tese de Clark nos textos nietzschianos do último período (nos quais estaria a posição de Nietzsche por ela advogada), ponto criticado por Peter Poellner (Poellner, P, Nietzsche and Metapbysics, p. 23) e Anderson, este último no artigo "Overcoming charity: the case of Maudemarie Clark's 'Nietzsche ontruthandphilosophy"' (Anderson, R. L. "Overcoming charity: the case of Maudemarie Clark's 'Nietzsche on truth and philosophy'"'. In: Nietzsche-Studien, n. 25, 1996, p. 315).

32. "Embora o perspectivismo recuse a verdade metafísica, ele é perfeitamente compatível com a compreensão da verdade a partir da mínima correspondência, e portanto com afirmar que muitas crenças humanas são verdadeiras. Ele até parece demandar a aceitação dessa teoria mínima, uma vez que esta é simplesmente o que resta da verdade uma vez que tenhamos rejeitado o que o perspectivismo rejeita, isto é, a coisa-em-si. O perspectivismo consiste portanto numa expressão metafórica daquilo a que chamei a posição neo-kantiana de Nietzsche a respeito da verdade. Essa posição não precisa negar um importante sentido em que nossa capacidade para a verdade é limitada, a saber, em que há sempre muito mais verdades do que qualquer ser humano é capaz de conhecer. Nós somos, afinal, criaturas finitas com uma quantidade limitada de tempo para descobrir verdades, enquanto que certamente há um número infinito de verdades por descobrir." Clark, M. Nietzsche on truth and philosopby, p. 135.) É de registrar-se o considerável simplismo não só da interpretação proposta para o modo como Nietzsche entende a verdade, mas sobretudo a compreensão do que seria a noção kantiana de verdade: se a epistemologia de Kant afirma uma "correspondência mínima", isto se deve, desde que adotemos uma leitura realista de sua posição, à afirmação da existência efetiva dos fenômenos, isto é, o seu "em si imanente", e não à mera 
pretensões metafísicas - que os filósofos de língua inglesa, diga-se de passagem, já há muito lançaram ao fogo -, mas mantidas as intenções de conhecer, falar, escrever, comunicar etc., sobram apenas, à parte os dados da experiência - base única das ciências, também valorizada por Nietzsche -, os pressupostos elementares de nossos hábitos cotidianos, da linguagem natural, das crenças mais elementares, e assim por diante.

Quando Nietzsche, portanto, faz afirmações sobre o ser humano e o mundo, ele busca embasamento ou nas ciências naturais, em cuja força parece ter sempre acreditado, ou nas suas próprias percepções acerca dos fenômenos avaliados, segundo o mesmo tipo de ótica que preside as percepções e afirmações do senso comum, variando apenas o grau de sofisticação e complexidade da análise. E a imagem do perspectivismo, deste ponto de vista, à parte servir para criticar a teoria metafísica da verdade como correspondência, teria ainda a função de ilustrar a circunstância, habitualmente reconhecida (pelo menos nas sociedades ocidentais contemporâneas), de que cada um pensa de um jeito a respeito de assuntos para os quais não existam comprovações empíricas ou demonstrações lógicas - sem exclusão da possibilidade de que o conflito entre duas perspectivas divergentes seja solucionado segundo o critério, também imanente à comunicação humana, da aceitabilidade racional. Comentando, por exemplo, o conflito que se estabelece, notadamente na Genealogia e no Anticristo, entre a perspectiva nietzschiana, dita verdadeira pelo próprio filósofo, e aquela do cristianismo, que, também segundo Nietzsche, conteria diversas mentiras, Maudemarie Clark faz as seguintes considerações:

A questão, portanto, é se o perspectivismo nega a possibilidade de que uma perspectiva seja superior a outra. Dada a minha leitura da metáfora, uma insistência na igualdade cognitiva das perspectivas deve basear-se na assunção de que apenas a coisa-em-si poderia fornecer o padrão comum ou neutro que seria necessário para comparar perspectivas. Mas tal conclusão parece desnecessária. Eu sugeri como alternativa (...) os padrões ou interesses da aceitabilidade racional. Isto é, nós pensamos uma perspectiva como superior a outra se ela, mais do que esta, dá aos ocupantes de ambas as pers-

correspondência dos conceitos às intuições, que seria tão somente o be-a-bá da primeira Crítica. 
pectivas o que eles estariam esperando de uma teoria - satisfazendo melhor aos seus padrões de aceitabilidade racional. ${ }^{33}$

O que fica assim sugerido, portanto, é que Nietzsche, ao defender determinadas ideias em que acredita, mobilizando uma série de elementos argumentativos e retóricos em seu favor, está na verdade adotando um procedimento cuja essência é a mesma de qualquer debate opinativo de ideias, seja ele entre indivíduos comuns ou filósofos de elevada erudição - procedimento do qual faria parte a expectativa de que outros seres humanos, por partilharem certos pressupostos linguísticos comuns, possam deixar-se persuadir por suas ideias e terminar por aderir a elas. Ainda que se pudesse desde logo, como faz Poellner, questionar a sustentabilidade de uma tal posição na própria letra do texto nietzschiano - pretensão contida na tese de Clark -, é interessante notar como, face à necessidade de uma superação lógica do solipsismo, de um lado, e a necessidade de prestar contas das afirmações feitas pelo filósofo, de outro - dizer que são metáforas com pretensões estritamente críticas seria aqui fugir ao problema -, as ideias de crença e intersubjetividade tornam-se centrais nessa tentativa de reinterpretar o perspectivismo nos quadros da filosofia analítica. Partindo também das afirmações feitas por Nietzsche a respeito da psicologia humana, ou do que seriam as nossas experiências internas, Poellner desenvolve a seguinte análise (cujo parentesco com as "intenções de Clark" ele próprio não deixa de admitir): ${ }^{34}$

Quando Nietzsche diz que as pessoas costumam errar ao distinguir entre 'fato' e 'interpretação' na experiência interna, e que as suas interpretações de seus próprios estados mentais são frequentemente falsas, ele está, de acordo com a presente leitura, afirmando as seguintes coisas. Ele acredita ser verdadeiro (para ele, ou 'perspectivamente') que há outros 'sujeitos' que têm uma 'vida subjetiva invisível', isto é, estados mentais com um certo caráter fenomênico. Ele

33. Idem, pp. 140-1.

34. "O recente livro de Maudemarie Clark sobre Nietzsche compartilha em alguns aspectos, mais do que as outras interpretações mencionadas, as intenções do presente estudo. Seu projeto é, em grande medida, um projeto crítico-filosófico, e ela, por assim dizer, aborda Nietzsche a partir "de fora", interrogando seus enunciados de um ponto de vista que, no seu caso, é fortemente influenciado por recentes filósofos pragmatistas e antirrealistas". Poellner, P. Nietzsche and Metapbysics, p. 22. 
também acredita que esse caráter, ou a aparência do que ele seja, pode ser, em seus aspectos afetivos e apetitivos, descrito corretamente em termos fornecidos por sua noção da vontade de potência. Ele ainda defende - salvo prevaricações ocasionais - que a 'correção' de tal descrição significa que ela poderia ser reconhecida, desde que havendo suficiente atenção (isto é, na ausência do autoengano), como sendo correta por todos aqueles sujeitos a cujos estados ela se refere. ${ }^{35}$

Que Nietzsche acredite naquilo que diz - pressuposto presente nas três afirmações de Poellner - acaba tendo, aqui, um sentido similar ao que tinha para Maudemarie Clark, nos termos do princípio da equivalência: quem afirma algo (como verdadeiro) acredita na verdade daquilo que está afirmando. ${ }^{36} \mathrm{E}$ que todo ser humano, ao falar ou escrever, esteja baseado em determinadas crenças, seria algo logicamente anterior a qualquer autocrítica teórica: quando alguém, por exemplo, muda de perspectiva, indo além (ou aquém) da crença inicial, é porque se viu persuadido e sua crença mudou, sem que tenha havido algum momento de não-crença absoluta. Que esta movimentação entre perspectivas ocorra, porém - e Nietzsche parece acreditar que sim, ao dirigir-se persuasivamente a seus leitores -, isso depende de determinados pressupostos, talvez também acreditados em função do contexto intersubjetivo, mas sempre e necessariamente presentes, e aos quais o perspectivismo nietzschiano tem de estar de algum modo atrelado. É isso o que Poellner tem em mente quando fala, a partir das considerações acima, de um sentido "mais substancial" de verdade, em comparação com o sentido inteiramente relativista que uma versão forte do perspectivismo lhe emprestaria: sem tal sentido pressuposto, perderiam todo significado a crítica nietzschiana às "mentiras" do platonismo-cristianismo, bem como suas análises psicológicas da moralidade, suas reflexões a respeito do corpo e até as tantas afirmações que faz sobre si mesmo (cf. idem, pp. 298-9).

35. Idem, p. 257.

36. O "como verdadeiro" dependeria do contexto, naturalmente: o ator numa peça, ou quem está mentindo deliberadamente, afirmam sem acreditar. Quem defende posições em livros de filosofia não está, supostamente, empenhado em enganar os seus leitores - ou, se o faz por vezes, é, conforme a crítica de Poellner a Derrida, em contraste com aspectos não enganadores de seu discurso (como seria o caso da vontade de potência, o eterno retorno etc.). 
Também presente em Hales e Welshon, que falam num "perspectivismo fraco", ${ }^{37}$ seria portanto comum às leituras "analíticas" essa tendência a mitigar o perspectivismo de Nietzsche, de modo a tornar sustentáveis, se não todos, pelo menos alguns dos demais aspectos de seu pensamento; mitigação que se funda muito mais numa identificação dos pressupostos implícitos ao filosofar nietzschiano do que em reflexões explícitas deste a respeito do problema. Uma vez que a filosofia analítica, como se sabe, assume a existência de um progresso no conhecimento filosófico, baseado tanto na lógica e nas ciências como na própria evolução do debate filosófico, tornou-se uma espécie de regra metodológica, conhecida como "princípio da caridade", essa tentativa de "salvar o filósofo dele mesmo", eliminando eventuais contradições, admitindo elementos implícitos como constitutivos do sistema, abandonando teses que sejam insustentáveis face à ciência recente, e assim por diante. Não é à toa que Maudemarie Clark, por exemplo, levando aparentemente mais a sério esse princípio, tenha recusado com veemência a interpretação de vontade de potência e eterno retorno como predicados atribuíveis ao mundo ou ao homem, numa visão cosmológica que Nietzsche acreditasse verdadeira no mesmo sentido em que acredita verdadeiras as análises históricas e psicológicas acerca do cristianismo e do homem de seu tempo (estas, sim, passíveis de veracidade no sentido examinado há pouco). Seria um absurdo, por exemplo, considerar a vontade de potência (ou, no caso, de poder $)^{38}$ como definidora do comportamento humano, do ponto de vista empírico (a partir de observações do comportamento humano), porque

o caráter elucidativo de explicações do comportamento em termos do desejo pelo poder depende de um contraste implícito com outras motivações, perdendo seu valor assim que todas as outras motivações sejam interpretadas como expressões da vontade de poder. O caráter elucidativo de explicações contemporâneas sobre o estupro em termos de poder, por exemplo, parecem depender do contraste implícito entre desejo pelo poder e desejo pelo sexo. O que o estu-

37. Cf. Hales e Welshon, Nietzsche'sPerspectivism,pp. 18 e ss.

38. Embora a tradução de Wille zur Macht por "vontade de potência" seja a nossa opção, a forma como Clark emprega o termo, na citação aí trazida ao texto, sugere que, no seu caso, o "power" de willtopower esteja mais próximo do nosso "poder", no sentido mais corriqueiro da palavra. 
prador quer, fundamentalmente, não é a gratificação sexual, mas um sentimento de poder. Esta explicação perde seu caráter elucidativo se alguém a partir disso afirma que todo comportamento é motivado por um desejo pelo poder, pois então a motivação para o estupro não foi diferenciada de nenhuma outra motivação. ${ }^{39}$

Não sendo possível, como gostariam alguns ${ }_{1}^{40}$ fundar o conceito de vontade de potência na experiência, seja enquanto essência do homem, seja enquanto essência do mundo, torna-se então necessário, prossegue Clark, interpretá-lo na chave do "perspectivismo forte", isto é, como o modo de ver o mundo que é próprio a Nietzsche em função de suas idiossincrasias, algo perfeitamente compatível com a noção de verdade que a vimos defender há pouco. Afinal, uma vez fechadas as portas da metafísica essencialista, e abertas as portas do debate opinativo acerca dos mais variados assuntos, Nietzsche pode perfeitamente participar desse debate, ora lastreando suas afirmações em induções cuidadosas (como teria sido o caso em algumas de suas análises da cultura cristã), ora lastreando-as em elementos puramente subjetivos ou estritamente datados - cabendo ao leitor, como faz Clark, separar umas das outras. E o eterno retorno, como já se pôde adivinhar, estaria também entre as afirmações do segundo tipo: sem qualquer pretensão cognitiva, Nietzsche estaria apenas oferecendo uma ideia, a partir de suas vivências e características pessoais, para pensar o mundo, o homem, a questão moral, a questão do tempo etc.

Seja como for, o fato é que se constitui assim, no modo de compreender os conceitos que delineiam a chamada face construtiva da filosofia nietzschiana, um sistema de leitura próprio a essa linha de interpretação que analisamos aqui: recusando com veemência o relativismo dos franceses, os comentadores analíticos tentam trazer Nietzsche para a cena contemporânea livrando-o dos ranços que pudessem ligá-lo a um passado metafísico e identificando as condições possibilitadoras do seu próprio discurso, para poder assim aproveitar toda a riqueza oferecida por sua obra no sentido de alimentar a nossa

39. Clark, M. Nietzsche on truth and pbilosopby, p. 210.

40. Clark dialoga, nesse contexto de seu livro, com Walter Kaufmann, cuja leitura seria, com efeito, das mais calcadas no empirismo como chave para compreender os principais conceitos téticos de Nietzsche. Cf. Kaufmann, W. Nietzsche: philosopher, psychologist, antichrist. Nova York: The World Publ. Co., 1965 . 
compreensão dos vários temas que abordou - o comportamento humano, os tipos por ele analisados (o homem moderno, o padre etc.), a história do cristianismo etc. Embora não se trate, na maioria dos casos, de temas propriamente científicos, o diálogo acerca deles estaria submetido às tais condições de aceitabilidade racional de que nos fala Poellner e, desse ponto de vista, a qualidade das análises nietzschianas poderia ser medida, até certo ponto, pelo sucesso que tiveram junto aos tantos leitores que, "em mais de um século, nelas encontraram estímulo e interesse".

\section{Um possível balanço}

Embora se possa reconhecer a validade, de um ponto de vista "lógico", de boa parte desses argumentos- sobretudo no que diz respeito aos pressupostos subjacentes à comunicação, aparentemente negligenciados pelos franceses -, é também forçoso reconhecer o quanto essa leitura se faz à revelia do filósofo, num espírito muitas vezes reducionista e mesmo conflitante com o que sentimos emanar do movimento de seus textos. A ideia de "melhorar" o filósofo que abomina os "melhoradores da humanidade", por si só, parece indicar uma "contradição" que, talvez irrelevante numa consideração estrita acerca das condições de possibilidade das afirmações nietzschianas (afirmações com que analisa e critica os próprios "melhoradores"), correria o risco de contaminar o comentário com um flagrante "antinietzschianismo", assim como a aproximação de Nietzsche ao senso comum, o excessivo peso dado à sua eventual preocupação com a comunicação etc. Ainda que tudo isso o torne, possivelmente, mais palatável a certo "gosto" hoje em voga - constituindo razão suficiente para a vitória de tal perspectiva sobre as demais, segundo "padrões de aceitabilidade racional" -, uma leitura mais detida de sua obra, portanto menos sujeita ao ponto de vista sempre suspeito do "consenso" e do "presente", deveria levar mais a sério a sua riqueza de significados.

Não devemos deixar de reconhecer, no entanto, o valor contido nessa pressão argumentativa, por assim dizer, que é exercida pela interpretação analítica: se não queremos incorrer nem no relativismo dogmático nem em alguma espécie de nietzschianismo dogmático, é preciso que nos esforcemos para prestar contas dos pressupostos a partir dos quais nossa fala se constitui. Dizer, por exemplo, que a realidade é relacional, plural e cambiante pode até representar uma total inversão dos pressupostos ontológicos que dominaram a maior parte 
da história filosófica ocidental, mas não traz consigo nenhuma evidência de sua veracidade. Admitir, por outro lado, que isso seja um conjunto de hipóteses, pessoais e datadas - mas, ainda assim, talvez verdadeiras-, constitui uma ressalva que, de certo modo, imuniza o discurso nietzschiano não apenas contra as acusações de ingenuidade e dogmatismo, como também contra aquela de irrelevância - que justificaria o abandono da vontade de potência e do eterno retorno por parte dos analíticos.

Afinal, se não aceitarmos tão facilmente a transferência acrítica do padrão científico de progresso para o âmbito da reflexão filosófica, podemos tomar a ideia do "padrão de aceitabilidade" num sentido alargado e admitir que haja, na filosofia, contextos veritativos distintos que não tenbam de extinguir-se uns aos outros. Se num desses contextos predomina o ânimo pragmático, por assim dizer, à luz do qual a cosmologia nietzschiana, "ultrapassada", é irrelevante e digna de desprezo, em outro pode predominar o ânimo contemplativo - a vita contemplativa de que Nietzsche, em geral crítico, é também um entusiasmado apologista (cf. FW/GC, § 329) - e, assim, o respeito e a admiração por esses empreendimentos "doadores de sentido" que, como a cosmologia (ou "metafísica") nietzschiana - aqui, por sinal, a acusação heideggeriana deixaria de ser um problema -, colaboraram para enriquecer, ao longo dos últimos milênios, a autocompreensão do homem enquanto ser no mundo. ${ }^{41}$

41. A relação de Nietzsche com a tradição filosófica é bem mais ambígua do que se costuma pensar. Embora o ideal ascético, dominante na filosofia ocidental de Platão a Schopenhauer, seja duramente combatido por Nietzsche, que almeja superá-lo, sua função histórica não foi apenas negativa. Pelo contrário: como nos mostra o último parágrafo da Genealogia da Moral, ele serviu também para "interpretar o sofrimento". "A interpretação - não há dúvida - trouxe consigo novo sofrimento, mais profundo, mais íntimo, mais venenoso e nocivo à vida: colocou todo sofrimento sob a perspectiva da culpa... Mas apesar de tudo - o homem estava salvo, ele possuía um sentido, a partir de então não era mais uma folha ao vento, um brinquedo do absurdo, ele podia querer algo - não importando no momento para que direção, com que fim, com que meio ele queria: a vontade mesma estava salva." (GM, III, 28) Compreende-se assim que os novos filósofos sejam instados por Nietzsche a percorrer também a perspectiva da filosofia ocidental, contanto que não fiquem nela, mas a superem (cf. BM, §§ 41-44). 
Desse modo, seria possível ficar com a riqueza retórica e simbólica dos franceses e, ao mesmo tempo, responder satisfatoriamente às exigências epistêmicas dos anglo-saxões. Onde Nietzsche, pensando certamente num interlocutor britânico, afirma que, se sua teoria for uma mera interpretação, "então tanto melhor" (JGB/BM, § 22), deveríamos acrescentar, mais de um século depois, que foi melhor ainda ela ter sido uma teoria de amplo sucesso e aceitação junto a boa parte dos 'filósofos do futuro'. Se a "razão insular", desde sempre avessa às especulações metafísicas, preservou de Nietzsche o ceticismo e o desprezo por nosso passado filosófico, a "razão continental", desde sempre mais aberta aos possíveis voos do pensamento criador, segue até hoje debruçada sobre os textos com que Nietzsche, munido de suas instigantes hipóteses sobre a alma humana - entre as quais a vontade de potência, o eterno retorno e o além-do-homem -, tornou-se e segue a ser, sem nenhuma "pesquisa empírica" a respaldar-lhe (o que é perfeitamente condizente com o seu conceito de experiência), um dos grandes "filósofos-psicólogos" (BM, § 45) da época contemporânea.

\section{Referências bibliográficas}

ANDERSON, R. L. "Overcoming charity: the case of Maudemarie Clark's 'Nietzsche on truth and philosophy'". In: Nietzsche-Studien, n. 25, 1996.

CLARK, M. Nietzsche on truth and pbilosopby. Cambridge: Cambridge Univ. Press, 1990.

DELEUZE, G. Nietzsche et la philosopbie. Paris: PUF, 1999.

DERRIDA, J. Éperons. Les styles de Nietzsche. Paris: Flammarion, 1978.

FOUCAULT, M. "Nietzsche, la genealogie, l'histoire". In: Balaudé, J-F. eWotling, P. (orgs.)Lectures de Nietzsche. Paris: Le Livre de Poche, 2000.

HALES, S. e WELSHON, R. Nietzsche's Perspectivism.Chicago: University of Illinois Press, 2000.

HEIDEGGER, M. Nietzsche, vol. 1. Tradução de Marco Antônio Casanova. Rio de Janeiro: Forense, 2007.

KAUFMANN, W. Nietzsche: philosopher, psychologist, antichrist. Nova York: The World Publ. Co., 1965.

LEBRUN, G. "Por que ler Nietzsche hoje?". In: Passeios ao léu. São Paulo: Brasiliense, 1983.

MATTOS, F. C. Nietzsche e o primado da prática: um espírito livre em guerra contra o dogmatismo. Tese de doutorado. 271 páginas. São Paulo: Depto. de Filosofia - FFLCH - USP, 2007. 
NIETZSCHE, F. SämtlicheWerke. KritischeStudienausgabe (KSA). 15 vols. Organizada por Giorgio Colli e MazzinoMontinari. Berlim, Nova York: W. de Gruyter, 1999.

Além do bem e do mal. Tradução de Paulo César de Souza. São Paulo: Companhia das Letras, 2001.

Ecce Homo.Tradução de Paulo César de Souza. São Paulo: Companhia das Letras, 1995.

- Gaia Ciência.Tradução de Paulo César de Souza. São Paulo: Companhia das Letras, 2001.

. Genealogia da Moral.Tradução de Paulo César de Souza. São Paulo: Companhia das Letras, 1998.

Obras incompletas. Coleção Os Pensadores. Tradução de Rubens Rodrigues Torres Filho. São Paulo: Abril Cultural, 1983.

POELLNER, P. Nietzsche and Metaphysics. Oxford: Clarendon, 1995. 